Mariusz Lach SDB

Wydział Nauk Humanistycznych

Katolicki Uniwersytet Lubelski Jana Pawła II

\title{
POSTACI BIBLIJNE WE WSPÓLCZESNYM POLSKIM TEATRZE RELIGIJNYM (PO 2000 R.)
}

Współczesny dramat religijny, który sam się tak określa, zniknął ze scen teatrów profesjonalnych. Czasy, kiedy można było spotkać się z dramatami Zawieyskiego, Brandstaettera czy choćby Wojtyły przeszły do historii. Wprawdzie można co pewien czas obejrzeć „,spektakle religijne”, jak chociażby Historyję o chwalebnym zmartwychwstaniu Pańskim przygotowaną przez Piotra Cieplaka ${ }^{1}$ dla teatru telewizji w 1996 roku, czy też zrealizowaną przez supraślański Teatr Wierszalin w 2016 roku w reżyserii Piotra Tomaszuka², to jednak należą one do rzadkości. I chociaż teksty te są często traktowane jako perły literatury, dające szerokie możliwości interpretacyjne, to ich realizatorzy nie nazywają swych dokonań działalnością na polu teatru religijnego. Tę przestrzeń wypełniają teatry amatorskie, coraz bardziej dbające o poziom profesjonalizmu w pracy nad dramatami.

Praktycznie od początków istnienia teatru religijnego w Polsce jest on związany ze scenami amatorskimi działającymi w cieniu kościoła. Misteria, jasełka czy żywoty świętych od dawna gościły na deskach scenicznych z okazji rozmaitych wydarzeń związanych z rokiem liturgicznym. W ostatnich latach, zwłaszcza po przemianach w 1989 roku, w naszym kraju zaczęły powstawać różnego rodzaju amatorskie teatry religijne, które dzięki swej systematycznej pracy i profesjonalnemu podejściu do materii warsztatowej mogą niejednokrotnie być źródłem zazdrości dla innych tego typu grup zawodowych ${ }^{3}$. Skupione przy różnych ośrodkach religijnych (parafie, szkoły, uczelnie) pracują systematycznie nad doskonaleniem swoich umiejętności, występując niejednokrotnie na profesjonalnych scenach. Takie grupy posiadają często swój własny status istnienia

${ }^{1}$ Historyja o chwalebnym Zmartwychwstaniu Pańskim, Mikołaj z Wilkowiecka, reżyseria: Piotr Cieplak, premiera 10 IV 1995, Teatr Telewizji Warszawa.

${ }^{2}$ Historyja o chwalebnym Zmartwychwstaniu Pańskim, Mikołaj z Wilkowiecka, reżyseria: Piotr Tomaszuk, premiera 20 III 2016, Supraśl..

${ }^{3}$ Por. M. Lach, Kilka szkiców na temat amatorskiego teatru religijnego dziś, Lublin 2009. 
(stowarzyszenie, fundacja), zaś działalność w tych zespołach jest dla aktorów w nich zrzeszonych często głównym zajęciem. Powstały one w całej Polsce najczęściej w większych ośrodkach miejskich takich jak Poznań (Teatr Droga), Gliwice (Teatr-A), Katowice (Teatr Franciszka), Łódź (Teatr Logos) czy Lublin (Teatr ITP). One to w swym repertuarze posiadają zarówno tradycyjne teksty literackie, jak i własne, autorskie spektakle. I dlatego też, właśnie w tych środowiskach można spotkać bohaterów opartych na swych biblijnych pierwowzorach.

Głównymi postaciami biblijnymi mającymi szczególne miejsce w teatrze religijnym są osoby Jezusa i Maryi. To właśnie One stoją w centralnym punkcie kerygmatu głoszonego przez chrześcijan. I dlatego w różnych formach scenicznych, które mają za swe główne zadanie przekazywanie najważniejszych treści chrześcijańskich postać Chrystusa, jak i Jego matki są podstawowymi. Twórcy najczęściej przedstawiają je w sposób bardzo tradycyjny. Zarówno w misteriach, jak i różnego rodzaju „obrazkach ewangelicznych” starają się je tak ukazać, aby były zgodne z konfesyjnymi wyobrażeniami.

W przypadku Jezusa - zwykle spotykamy brodatego mężczyznę w średnim wieku z długimi włosami. Wizerunek ten został przez wieki utrwalany na różnego rodzaju dziełach malarskich, ale jego ostateczny „rozkwit” nastąpił po realizacji głośnego filmu z 1977 r. Jezus z Nazaretu Franco Zeffirellego, gdzie w tytułową postać wcielił się Robert Powell. Ten obraz tak bardzo się wyrył w świadomości nie tylko odbiorców, ale i większości ludzi, że dzisiaj trudno sobie wyobrazić w tej roli osobę o innym wizerunku. Oczywiście, w teatrze nie zawsze mamy do czynienia z tak wyglądającymi aktorami, niemniej bardzo często do tego celu wykorzystywano różnego rodzaju elementy stylizacji ze sztuczną brodą włącznie.

Niezależnie od wizerunku zewnętrznego postać Zbawiciela ukazywana jest najczęściej jako ta wyjątkowa, bardziej boska niż ludzka, głosząca, niejednokrotnie $\mathrm{z}$ wielkim pietyzmem, ale i patetyzmem nauki Nowego Testamentu. Tak też funkcjonuje Jezus w spektaklach realizowanych przez amatorskie grupy teatralne. Zarówno w misteriach pasyjnych, jak i w krótszych scenkach ewangelizacyjnych, twórcy starają się ukazać osobę Chrystusa w sposób tradycyjny, niejednokrotnie ubierając go dodatkowo w biała szatę, z elementami typu szarfa lub czerwone serce. Związane jest to nie tyle z próbą kopiowania rzeczywistego stroju osób żyjących na przełomie wieków, ile z wzorowaniem się na malarstwie przedstawiającym Jezusa Miłosiernego, opartym na różnego rodzaju objawieniach, jak na przykład w przypadku siostry Faustyny Kowalskiej czy Katarzyny Emmerich.

Podobnie wygląda sytuacja z ukazywaniem na scenie Maryi. Mniej jest obrazów pokazujących ją jako żydowską młodą dziewczynę, natomiast więcej nawiązujących do malarstwa, gdzie Maryja ubrana jest najczęściej w błękitne szaty, z długi welonem, bądź chustą na głowie. Często w dłoniach 
trzyma dziecko (jasełka), może mieć na głowie koronę (królowa) lub, jak to bywa w przypadku pasji, ubrana jest w ciemne, żałobne (wg naszej kultury) szaty. Tak zbudowaną postać spotykamy na przykład w musicalu pt. Życie Maryi wspólnoty Guadalupe z Lublina ${ }^{4}$. Grana przez liderkę tejże wspólnoty - Agnieszkę Beszłej, jest ukazana w taki tradycyjny sposób, a przez to idealnie wpisuje się w ideę i charyzmat wspólnoty, która pragnie dzięki cotygodniowym spotkaniom modlitewnym, przez uwielbienie, śpiew i poznawanie Słowa Bożego przybliżać wiernym kult Matki Bożej z Guadalupe. Samo przedstawienie, oprócz formy musicalowej, skupiającej się na biblijnych wydarzeniach związanych z życiem Maryi, ma również część modlitewną, do której młodzi aktorzy zapraszają widzów. Nie należy się zatem dziwić tradycyjnemu podejściu do tematu.

Takie obrazy są bardzo popularne i przedstawiane w wielu realizacjach scenicznych. Jednak coraz częściej można spotkać delikatne odchodzenie od takiego ukazywania Jezusa i Maryi. W Ewangelii wg kobiet - musicalu w reżyserii Mariusza Kozubka zrealizowanym przez katowicki Teatr Franciszka ${ }^{5}$ obie postaci są zarysowane trochę mniej patetycznie. Są one bliższe widzowi. Jezus w spodniach i bluzie, grający na skrzypcach towarzyszy swoim bohaterkom stopniowo odsłaniając i wyjaśniając prawdy wiary, zaś Maryja - to młoda, radosna dziewczyna, w zwiewnej, stylizowanej na współczesność sukience. Ta „,nastolatka” poprzez śpiew i taniec opowiada historię swego zakochania w Józefie, aby przechodząc przez kolejne etapy życia swego Syna, stać się matką bolejącą. Zresztą cały pomysł opowiedzenia najważniejszych wydarzeń Ewangelii z perspektywy kobiet - Elżbiety, Marii i Marty, Herodiady, Salome czy też wskrzeszonej córki Jaira, jest zabiegiem bardzo intrygującym i na pewno nowatorskim w Polsce. Z jednej strony całość nie ma na celu zburzenia tradycyjnych pojęć dotyczących postaci z Ewangelii, zarazem jednak, przez ukazanie ich zwyczajności - widzowie oglądając znane skądinąd obrazy, przeżywają je na nowo i odkrywają kolejne znaczenia.

Trochę dalej w obrazowaniu Jezusa posunął się Teatr Droga z Poznania. W swoim repertuarze od 2000 roku posiada spektakl muzyczny Zraniony Pasterz ${ }^{6}$

${ }^{4}$ Zespót Guadalupe powstał w 2013 r. w Lublinie. Misją zespołu jest uwielbienie Boga razem z Maryją oraz krzewienie kultu Matki Bożej z Guadalupe. W skład zespołu wchodzą dzieci, młodzież i dorośli. Życie Maryi, scenariusz Agnieszka Beszłej, premiera 12 XII 2014, Lublin. Por. http://www.guadalupe.com.pl.

${ }^{5}$ Teatr Franciszka to amatorska grupą artystów, powstała w październiku 2013 roku. Poprzez pasję, którą jest teatr, pragną niekonwencjonalnie przedstawiać światu biblijny przekaz, dzieląc się cząstką siebie zarówno z widzami, jak i z sobą nawzajem. Ewangelia wedlug kobiet, scenariusz i reżyseria: Mariusz Kozubek, premiera 11 V 2017, Katowice.

${ }^{6}$ Teatr Droga, powstały w Poznaniu w 1998 roku. Jego celem jest ewangelizacja i rozpowszechnianie, szczególnie w środowiskach młodzieżowych, wiary w Jezusa Chry- 
oparty na książce Daniela Ange. Jest to historia współczesnego młodego człowieka - narkomana, który pozbawiony nadziei błąka się po swoim mieście. Jego przewodnikiem staje się Pasterz - Jezus wędrujący w poszukiwaniu zagubionych owiec. Wygląda on bardzo współcześnie. Nie posiada żadnej szaty wzorowanej choćby na pasterskim stroju. Jest to młody, przeciętny mężczyzna w jeansach i zwyczajnej bluzie. To co go charakteryzuje, to chęć wysłuchania napotkanych ludzi, pragnienie dawania im otuchy, poczucia bezpieczeństwa i nadziei. Forma ukazania osoby Mesjasza przez poznański teatr, podobnie jak w poprzednim przypadku, koresponduje z założeniami ewangelizacyjnymi grupy. Dlatego grany z przerwami od kilkunastu już lat, wciąż jest jednym z ważniejszych przedstawień teatru - wspólnoty.

Rozważając postaci Jezusa i Maryi obecne w teatrze przez wieki i mające wyjątkowe i stałe miejsce w kulturze europejskiej, należy zauważyć, że co pewien czas jest większa albo mniejsza „moda” na ukazywanie innych bohaterów biblijnych. Wiąże się to z różnym nastawieniem odbiorców zależnym od sytuacji społecznej, jak i od aktualizowania w określonym czasie prawd religijnych. Często z rozważaniem problemu zdrady, wolnej woli czy też z próbą usprawiedliwiania zła pojawiały się teksty bazujące na postaci Judasza. Tak było u Karola Rostworowskiego w Judaszu z Kariothu (1913) czy w późniejszym Żegnaj Judaszu (1971) Ireneusza Iredyńskiego. Dramaty te starały się wejść w polemikę dotyczącą wolności i odpowiedzialności za nią, posługując się osobą biblijnego zdrajcy. Natomiast w przypadku innych postaci: apostołów czy też świętych - próbowano w dramatach ukazać ich wyjątkowość i nieskazitelność.

Inaczej wygląda sprawa z pozostałymi postaciami biblijnymi we współczesnym teatrze religijnym. Zauważa się ostatnio wyraźny powrót do wielkich osób ze Starego Testamentu. Teatry w swoim repertuarze opowiadają historie patriarchów (Abrahama, Izaaka, Jakuba, Mojżesza), dotykają problematyki proroków (Jonasz, Izajasz, Jeremiasz, Daniel), a także co pewien czas powołują do istnienia osoby anonimowe, ale mające swe pierwowzory na kartach Pisma Świętego (bohaterowie przypowieści Jezusowych, Nikodem). Jednak celem owych działań teatralnych coraz rzadziej jest przypomnienie samej historii konkretnych osób. Twórcą ukazują życie postaci biblijnych w celu stworzenia lustra, w którym odbija się dzisiejsza rzeczywistość. Warto się przypatrzeć kilku wybranym przykładom.

Abraham - praojciec ludu wybranego, mąż zaufania. Jego wyjście do ziemi obiecanej, zawierzenie Bogu w sprawie licznego potomstwa oraz próba wiary są

stusa. Zraniony pasterz, scenariusz: Helena Sperska-Abbe na podstawie książki „Zraniony Pasterz" o. Daniela Ange, reżyseria: Marta Skoraszewska, Wojciech Duchant, premiera 10 XII 2000, Poznań. Por. http://www.teatrdroga.pl [dostęp 15.12.2017 r.]. 
częstym tematem wykorzystywanym w głoszeniu konkretnej nauki. Ten patriarcha stał się bohaterem spektaklu zrealizowanego przez Gliwicki Teatr-A pt. Moria - samotność milczenia ${ }^{7}$, przez łódzki Teatr Logos w spektaklach: Wiara Nadzieja Miłość i Komedyja $a^{8}$ oraz przez studencki Teatr ITP działający przy Katolickim Uniwersytecie Lubelskim Jana Pawła II w spektaklu muzycznym również o tytule: Moria ${ }^{9}$. W tym ostatnim przypadku historia Abrahama ukazana jest w trochę przewrotny sposób. Otóż widzowie spotykają rodzinę zmarłego patriarchy po uroczystościach pogrzebowych ojca narodów. Z całego jego dobytku pozostał tylko płaszcz i podróżny kapelusz. I oto ta postać, która otrzymuje owe atrybuty Abrahama, zaczyna snuć historię życia zmarłego. Ubierając znoszone rzeczy, staje się na chwilę protagonistą ludu wybranego. Widzimy postać Abrahama oczami różnych ludzi, którzy mieli do niego ambiwalentny stosunek. Zatem raz ukazany jest jak ten, który wyprowadził Izraelitów z Ur chaldejskiego (zob. Rdz 12,4-5). Chwilę później spotkać go można jako człowieka bojącego się faraona i z powodu lęku o siebie i pobratymców nazywającego swą żonę siostrą (zob. Rdz 12,9-20). Jest też Abraham proszący Boga o litość nad Sodomą i Gomorą (zob. Rdz 18,23-33) - nie jednak z powodu szlachetności uczuć do mieszkańców tych miast, ile z troski o własną rodzinę. Cały zbiór tych przeróżnych obrazków sprawia, że oczom widzów jawi się człowiek słaby, często upadający, jednak walczący ze swymi przywarami i nade wszystko ufający Bogu. To nie jest następny spiżowy pomnik postawiony „ku czci”, dzięki czemu widz może się utożsamić z sylwetką bohatera biblijnego; staje się on mniej odległy od współczesnego widza.

Postacią porównywalną do Abrahama i jego znaczenia dla wiary jest Mojżesz. Jest to święty prawodawca Izraela. Osoba, której wydawałoby się, że również nie można ukazać inaczej niż patetycznie. Próby pokonania tej trudności podjęła się wielka grupa osób pod przewodnictwem Mariusza Kozubka, przygotowująca w 2014 roku w katowickim Spodku megawidowisko Exodus ${ }^{10}$. To opowieść

${ }^{7}$ Teatr $-A$ jest offowym, autorskim, zawodowym teatrem religijnym. Działając od 1996 r. ma w swoim dorobku blisko trzydzieści premier oraz wiele innych przedsięwzięć artystycznych, w tym prowadzonych warsztatów teatralnych dla dzieci i młodzieży w Polsce i za granicą. Moria - samotność milczenia, scenariusz i reżyseria: Leszek Styś, premiera 2 IV 2016, Warszawa. Por. www.teatr-a.art.pl.

${ }^{8}$ Teatr Logos rozpoczął swoją działalność 2 XI 1987 r. w Łodzi. Do tej pory przygotował 50 spektakli premierowych. Wiara, Nadzieja, Miłość, reżyseria: Roman Komassa, premiera 8 IX 1996, Łódź; Komedyja, reżyseria: Bogusław Kierc, premiera 12 IX 1999, Łódź. Por. www.logos.art.pl.

${ }^{9}$ Teatr ITP - zespół został założony w 2001 r. na Katolickim Uniwersytecie Lubelskim Jana Pawła II, Moria, reżyseria: Mariusz Lach, scenariusz: Marcin Wąsowski, premiera 28 XI 2014, Lublin. http://itp.kul.lublin.pl.

${ }^{10}$ Exodus to widowisko utkane z mocnych, energetycznych obrazów, ilustrowanych muzyką symfoniczną. Ruch, taniec, gigantyczne formy scenograficzne, ekrany z projekcja- 
o ucieczce Izraelitów z Egiptu, przejściu przez Morze Czerwone i dotarciu do upragnionej krainy wolności - Kanaan. Twórcy zaprosili do współpracy kilkusetosobową grupę młodzieży, należącą do różnych teatrów, zespołów wokalnych czy tanecznych. Cała opowieść rozgrywała się w bardzo współczesnej, wręcz futurystycznej scenografii, składającej się z dużej liczby ruchomych, kilkumetrowych rusztowań budowlanych. Egipt - to kraj fałszywych reklam i ułudy, zaś sam Mojżesz to młody chłopak, marzący o zamieszkaniu ze swą ukochaną Sarą w małym domku. Bóg, który został zagrany przez wokalistkę Ewę Urygę, aktora teatru śląskiego - Edwarda Krawczyka oraz małego chłopca - Macka Frączkowskiego, wkracza w życie młodego Mojżesza. Ten ostatecznie, po różnych perypetiach, wątpliwościach i rozmowie z samym Stwórcą postanawia wypełnić Jego wolę. Nie ma tutaj może wyjątkowego odejścia od znanej historii, ale umieszczenie tej opowieści w dzisiejszym, konsumpcyjnym świecie sprawia, że znane nam wydarzenia nabierają innych, aktualnych znaczeń. Mojżesz ukazany jest jako człowiek poszukujący, ufający i wiernie realizujący wolę Bożą. Ubrany w kostium współczesny, bez brody i innych temu podobnych akcesoriów - staje się bliższy współczesnemu, zwłaszcza młodemu widzowi. Zabieg ten jest niejako zaproszeniem każdego człowieka, różnych (także nam współczesnych) czasów do udziału w boskich planach i odważnego ich realizowania.

Ten sam reżyser i autor scenariusza, czyli Mariusz Kozubek, kilka lat wcześniej zrealizował w Teatrze - $A$ (którym wtedy jeszcze kierował) musical o życiu króla Dawida ${ }^{11}$. Opowieść ta jest tradycyjnym przeniesieniem wydarzeń biblijnych opartych na wątkach historii z 1 i 2 Księgi Samuela w bliżej nieokreślone czasy. Kostium i cała oprawa scenograficzna stanowią zaproszenie do poznania wydarzeń z życia pierwszego króla Izraela. Trochę inaczej podszedł do tego tematu Teatr ITP. W Weselu Dawida ${ }^{I 2}$, autorstwa Marcina Wąsowskiego, spotykamy gości bawiących się podczas zaślubin króla z Batszebą. I chociaż jest tajemnicą poliszynela, że to władca kazał zabić Uriasza (zob. 2 Sm 11,14-15), aby wdowę po nim pojąć za żonę (zob. 2 Sm 11,26-27), nikt tego głośno nie mówi. Kontekst czasowy przenosi nas w okres przełomu XIX i XX wieku. Kostiumy, wykonywana na żywo klezmerska muzyka oraz scenografia wskazują, że nie będzie to opowiadanie historii znanej z kart Biblii, a raczej refleksja nad

mi multimedialnymi, około 130 aktorów i statystów, ponad 60 tancerzy, chór, balet, grupa kulturystów. Scenariusz i reżyseria: Mariusz Kozubek, premiera 16 X 2014, Katowice.

${ }^{11}$ Dawid - spektakl Teatru-A, oparty na wątkach historii Króla Dawida. W przedstawieniu biblijna opowieść rozgrywa się w dwóch planach czasowych, czas teraźniejszy to historia grzechu Króla i Batszeby. Retrospekcje opowiadają o karierze młodego Pasterza - Dawida. Scenariusz i reżyseria: Mariusz Kozubek, premiera 16 X 2010, Gliwice.

${ }^{12}$ Wesele Dawida to tragikomiczna historia zaślubin biblijnego króla Dawida z Batszebą umieszczona we współczesnych czasach zrealizowana przez lubelski Teatr ITP. Scenariusz i reżyseria: Marcin Wąsowski, premiera 9 XI 2013, Lublin. 
kłamstwem, obłudą i manipulacjami władców. Liczne aluzje do bezgranicznego decydowania o wszystkim przez króla, nawiązania do współczesnego świata polityki i sposobów jej funkcjonowania, a także ukazanie sposobów zacierania prawdy nawet przez największych - sprawiają, że Wesele Dawida jest smutnym obrazkiem dzisiejszego świata. Król nie jest postacią, która mogłaby być wzorem dla innych, i dlatego (w nawiązaniu do Wesela Wyspiańskiego) w pewnym momencie pojawiają się duchy, aby wpłynąć na myślenie władcy. One to sprawiają, że ostatecznie Dawid sam uznaje swój grzech i słabość. Dopiero teraz może prawdziwie przewodzić powierzonemu mu ludowi. Okazało się, że dla widzów taka postawa jest bliższa, bardziej prawdziwa i psychologicznie uzasadniona. Jest to kolejne odejście od monumentalnego odwzorowywania jednego z wielkich postaci Izraela. Niczego mu nie odbierając, ani nie uwłaczając jego wielkości, twórcy Teatru ITP, przybliżyli króla współczesnemu odbiorcy.

Abraham, Mojżesz czy Dawid - to postaci związane z historią narodu wybranego. Ich wiara, życie i panowanie w Izraelu sprawiają, że często są wzorcami do naśladowania czy też przypominają innym o podstawach wiary. Trochę inaczej wygląda sprawa z bohaterami - można rzec - baśniowymi, przypowieściowymi. Takimi są na przykład Jonasz czy Tobiasz. Losy obu postaci opisane zostały na kartach Starego Testamentu i należą do tzw. kanonu ksiąg mądrościowych. To dwie, wspaniale napisane historie, pełne przygód, mające swoją dramatyczną dynamikę i poruszające uniwersalne tematy.

Tobiasz jest młodzieńcem, który idąc w dalekie krainy, aby odebrać dług ojca, poznaje piękną Sarę - swą przyszłą małżonkę. Musi jednak najpierw stoczyć o nią walkę z demonem, by ostatecznie zwyciężyła miłość (zob. Tb 4-7). Takiego bohatera poznajemy w spektaklu Teatru-A pod tytułem Tobiasz ${ }^{13}$. To muzyczna opowieść o dojrzewaniu w drodze, wierności Bogu i potrzebie przyjaźni. Gliwiccy twórcy opowiedzieli to w sposób lekki i zabawny, umiejscawiając historię w realiach nawiązujących do współczesności. Zabawne dialogi, intrygi, piosenki pełne tańca sprawiają, że ta przypowieść staje się uniwersalną. Od czasu premiery w roku 1997 spektakl był grany wielokrotnie dla bardzo różnych grup młodzieży w całej Polsce. W ostatnim roku ten sam scenariusz został wykorzystany przez katowicki Teatr Franciszka, gdzie ciągle, z powodzeniem, ma swoich odbiorców. Jest to miła historia z dyskretnym morałem o aniołach i Opatrzności. Główny bohater jest ukazany w taki sposób, aby młody widz mógł się z nim utożsamić. Mamy więc zakochanego nastolatka, trochę roztargnionego, potrzebującego przyjaźni i marzącego o wielkiej miłości. Gdy się do tego doda

${ }^{13}$ Tobiasz to sceniczna, w pełni autorska adaptacja starotestamentalnej księgi. Grany przez Teatr- $A$ nieprzerwanie od dnia premiery niezmiennie bawi i wzrusza, przekazując dyskretnie pocieszającą prawdę o Aniołach i Opatrzności. Scenariusz i reżyseria: Mariusz Kozubek, premiera 19 X 1997, Gliwice. 
przygodową akcję, walkę z demonami i spotkanie z wymarzoną dziewczyną mamy do czynienia $\mathrm{z}$ ciekawym scenariuszem $\mathrm{w}$ niczym nie przypominającym patetycznych moralitetów. Zresztą cały dramat jest wiernym zobrazowaniem biblijnej księgi, ale podanym współczesnym językiem.

Drugim, również przygodowym bohaterem często powracającym w działaniach różnych teatrów religijnych jest Jonasz. Ta najkrótsza z ksiąg Starego Testamentu jest wzorcowo napisaną historią o wyraźnej puencie (zob. Jon 1-4). Temat ten jest często wykorzystywany w rozważaniach na temat wiary człowieka, jego odpowiedzi na powołanie oraz miłosierdzia samego Stwórcy. Jonasz jest człowiekiem lękliwym, któremu bliżej do rozleniwionych i nudzących się ludzi, niż do bohatera wybranego i mężnie głoszącego orędzie Boże. Jednak to ostatecznie on, nie mogąc się odciąć definitywnie od realizowania Bożego zamysłu, sprawia, że Niniwa się nawraca, a on sam będąc istotnym ogniwem w tym procesie, odkrywa istotę miłosierdzia Bożego. Pełen wątpliwości i nierozważny bohater, lękający się podjęcia zobowiązań, jest wspaniałą postacią, z którą mogą się identyfikować młodzi odbiorcy. Musical Jonasz ${ }^{14}$ zręcznie zrealizowany przez gliwicki Teatr- $A$, grany jest nieprzerwanie od 1996 roku. Początkowo stworzony był z myślą o dużej grupie młodzieży, później przedstawiany w wersjach kilkuosobowych, by wreszcie stworzyć opowieść realizowaną przez dwóch aktorów. Warto zauważyć, że rozbudowana wersja scenariusza została wystawiona w katowickim Spodku w ramach spotkania młodzieży w roku $2015^{15}$, kiedy do zespołu Teatru- $A$ dołączyła liczna grupa młodych aktorów, uczestników warsztatów teatralnych, i w ten właśnie sposób powstało widowisko o tym samym tytule.

Jonasz był tzw. prorokiem mniejszym i ukazanym w sposób zabawny. Lecz nie tylko w taki sposób są prezentowani bohaterowie biblijni. Nieco odmiennie wygląda sytuacja z tzw. prorokami większymi - jak Izajasz czy Jeremiasz. W 2009 roku Teatr ITP podjął się stworzenia i realizacji spektaklu rockowego pt. Prorock ${ }^{16}$. To historia oparta na fragmentach pochodzących z różnych ksiąg Starego Testamentu. Tytułowy bohater Prorok został stworzony na wzór Jeremiasza, Daniela i Izajasza. Opowieść nawiązuje w swej stylistyce do popularnych swego

${ }^{14}$ Jonasz to pierwsza sceniczna realizacja Teatru-A, oparta na starotestamentalnej Księdze Jonasza, opowiada historię proroka mimo woli, któremu nie w smak powierzona misja. Scenariusz i reżyseria: Mariusz Kozubek, premiera: 18 III 1986, Gliwice.

15 Twórcy widowisk Franciszek - wezwanie z Asyżu i Exodus oraz wspólnota młodzieżowa Niniwa w 10. rocznicę jej powstania zrealizowali musical Jonasz - sceniczną adaptację biblijnej Księgi Jonasza. Scenariusz i reżyseria: Mariusz Kozubek, premiera 17 II 2015, Katowice.

${ }^{16}$ Prorock - musical zrealizowany przez Teatr ITP, to historia człowieka, który chce być wierny swemu powołaniu. Scenariusz: Mariusz Lach, Marcin Wąsowski, reżyseria: Mariusz Lach, premiera 14 XI 2009, Lublin. 
czasu tzw. rock oper (np. Jesus Christ Superstar), zaś scenariusz nie jest zabawną komedią z morałem. To historia o człowieku nagle wybranym i posłanym do wykonania misji. Muzyka rockowa sugeruje bunt, sprzeciw, zarówno w stosunku do ówczesnych władców, jak i samego Boga. Tytułowy Prorok, niczym się nie wyróżniający spośród narzekającego na władzę i religię tłumu, nagle zostaje posłany. Po chwilach niepewności wykonuje polecenie, idzie do króla Nabuchodonozora z petycją, podejmuje zadanie zlecone mu przez Boga, aby ostatecznie wylądować w piecu ognistym. To historia o odkrywaniu swojej istoty, o potrzebie zatracenia się i zapomnienia o sobie, by zrealizować ważniejszą misję: być głosem sprzeciwu i stanąć w obronie ludu. Scenografia, kostiumy i cała stylistyka wskazuje na ludzi zbuntowanych, odrzuconych i pragnących tylko zachować swoją tożsamość. Główny bohater, mimo że przez chwilę czuje się wyjątkowym wybrańcem, ostatecznie upada na samo dno i dopiero wtedy, korzystając ze słów psalmów, na dnie rozpaczy uświadamia sobie swoje jestestwo, sens życia.

Ważną postacią biblijną, do której bardzo często sięgają twórcy dramatów, jest Hiob. Jest to osoba tragiczna poszukująca odpowiedzi na pytanie o sens cierpienia. Oczywiście temat ten pojawiający się co pewien czas w repertuarze teatrów zawodowych, jak na przykład w spektaklu Jerzego Zawieyskiego Mąż doskonały, jest na tyle trudny, że grupy młodzieżowe rzadko się podejmują jego realizacji. Teatr Karola pragnący kultywować i realizować sposób działania teatru rapsodycznego Mieczysława Kotlarczyka, a działający przy gliwickim Centrum Edukacyjnym im. Jana Pawła II, w roku 2012 zrealizował spektakl Karola Wojtyły pt. Hiob ${ }^{17}$. Młodzi aktorzy potraktowali ten dramat jako opowieść o Bogu wierzącym w człowieka, zaś w swojej interpretacji kierowali się ideami św. Jana od Krzyża. Jak czytamy w programie: „Zadziwiające jest jednak to, że [...] z ust Hioba nie słyszymy wołania o przywrócenie mu jego poprzedniego statusu, że nie pragnie on odzyskania dóbr materialnych, które utracił. Pragnie jednego - aby powróciła jego relacja z Bogiem. Lament Hioba wynika więc z miłości, z tęsknoty Stworzenia za Stwórcą"18.

Oprócz wyżej wymienionych postaci biblijnych pokazywanych przez różnego rodzaju teatry religijne warto zwrócić uwagę na inne, mniejsze spektakle, które może nie są w całości dedykowane konkretnym bohaterom, ale zawierają również najróżniejsze nawiązania do osób z kart Pisma Świętego. Najmłodsi odbiorcy mogli zobaczyć spektakle zrealizowane przez Teatr Eden ${ }^{19} \mathrm{z}$ Wieliczki.

${ }^{17}$ Teatr Karola, powstały w 2009 r., to teatr młodzieżowy, który od samego początku odwołuje się do spuścizny Teatru Rapsodycznego Mieczysława Kotlarczyka. Hiob to pierwszy spektakl teatru będący inscenizacją dramatu Karola Wojtyły. Reżyseria: Agata Wieczorek i Maciej Omylak, premiera: 21 X 2012, Gliwice. Por. http://teatrkarola.pl.

${ }^{18}$ Por. http://teatrkarola.pl/2012/09/29/byl-czlowiek-w-ziemi-hus.

${ }^{19}$ Teatr Eden, to teatr dla dzieci i młodzieży, powstały w 2013 roku w Wieliczce. Pragnie on edukować, wychowywać i uczyć bycia dobrym człowiekiem. Por. http:// teatreden.pl. 
Artyści stworzyli Historię Daniela w jaskini lwów oraz Arkę Noego - spektakle interaktywne, skierowane do dzieci w wieku 3-9 lat, w których maluchy same w nich uczestniczą w sposób kreatywny. Teatr $-A$ z Gliwic dla dzieci przygotował cykl noszący nazwę Biblijnego Teatru Dziecięcego ${ }^{20}$. W jego ramach zrealizowano dotąd dwa przedstawienia. Początek opowiadający „biblijną historię opisaną w pierwszych rozdziałach Księgi Rodzaju: stworzenie świata, grzech pierwszych ludzi, zesłanie potopu, wreszcie cudowne ocalenie ludzi i zwierząt w arce Noego". Drugim jest Sennik Józefa opisujący historię Józefa Egipskiego. W biblijną opowieść uwikłane zostają zwierzaki, gdyż Józef i jego rodzina to „charakterne” Psiaki, zaś późniejsze losy Józefa w Egipcie to konfrontacja bohatera ze światem kotów. Takie podejście do znanego tematu sprawia, że uczestniczące w przestawieniu dzieci poznają historię patriarchy przez zabawę.

Przytoczone wyżej przykłady spektakli nawiązujących do różnych postaci biblijnych, stanowią jedynie materiał poglądowy, ale również można z nich wyciągnąć odpowiednie wnioski. Po pierwsze, teatry religijne dostosowują formę do odbiorcy i założonych celów. Inaczej wyglądają spektakle mające przybliżyć ważne wydarzenia czy postacie biblijne, zaś inaczej te, dla których wydarzenia biblijne są tylko punktem wyjścia do własnych rozważań. Jest to sposób pracy, który dotąd był właściwy teatrom zawodowym. W okresie intensywniejszego rozwoju amatorskich teatralnych grup religijnych, docenić należy ich profesjonalne podejście do tematów spektakli. Po drugie, postacie biblijne są coraz częściej „zdejmowane z piedestału" - tzn. ukazywane są jako osoby zwyczajne, często nie pozbawione wad, które jednak dzięki wytrwałości i zaufaniu Bogu realizują wielkie cele. Wreszcie po trzecie - teatry te, choć ciągle w mniejszości i spychane na margines wiedzy o współczesnym teatrze, są coraz intensywniej widoczne w przestrzeni publicznej. Wychodzą one z małych sal parafialnych, i dzięki wykorzystywaniu profesjonalnych środków, powinny być brane pod uwagę podczas wszelkich debat na temat współczesnego teatru (nie tylko religijnego).

\section{Bibliografia}

Clifford S., Herrmann A., Teatr przebudzenia, tłum. R. van de Logt, Warszawa 2003.

${ }^{20}$ Biblijny Teatr Dziecięcy to cykl przedstawień Teatru-A. Skierowany do najmłodszego widza. Ma on go zapoznać z różnymi biblijnymi treściami, niezmiennie obecnymi i aktualnymi w europejskiej kulturze. Początek opowiada biblijną historię opisaną w pierwszych rozdziałach Księgi Rodzaju, scenariusz i reżyseria: Mariusz Kozubek, premiera: 27 IX 2009, Gliwice; Sennik Józefa, opowiada historię Józefa Egipskiego, scenariusz i reżyseria: Leszek Styś, premiera 22 IV 2012, Gliwice. 
Czytanie dramatu. Miniatury analityczne, red. W. Kaczmarek, A. Jarosz, Lublin 2016.

Dramat $i$ teatr religijny $w$ Polsce, red. I. Sławińska, W. Kaczmarek, Lublin 1991.

Dramat i teatr religijny. Wyróżniki i paradygmaty. W stulecie urodzin Profesor Ireny Stawińskiej, red. W. Kaczmarek, J. Michalczuk, Lublin 2014.

Dramat i teatr sakralny, red. I. Sławińska, W. Kaczmarek, W. Sulisz, M. B. Stykowa, Lublin 1988.

Fręś J. A., Teatr młodzieżowy. Warsztat. Spektakl. Scenariusze, Rzeszów 2005.

Lach M., Kilka szkiców na temat amatorskiego teatru religijnego dziś, Lublin 2009.

Lach M., Teatr w przepowiadaniu. Refleksje teoretyczno-praktyczne, Przegląd homiletyczny 17(2013).

Lach M., Transformations of the Religious Theatre at the Beginning of the 21st Century, w: The theatre and religoius drama nowadays, red. A. Podstawka, Lublin 2016.

Osterwa Juliusz, Antygona, Hamlet, Tobiasz dla Teatru Społecznego, Wrocław 2007.

$W$ kręgu dramatu i teatru religijnego XX wieku, red. W. Kaczmarek, J. Michalczuk, Lublin 2007.

Woźniak J. P., Inscenizacje staropolskiego dramatu religijnego, Lublin 2010.

\section{Streszczenie \\ Postaci biblijne we wspólczesnym polskim teatrze religijnym (po 2000 r.)}

Teatr chrześcijański wielokrotnie starał się przekazywać prawdy wiary wskazując na różne postaci biblijne, jako wzorce do naśladowania. I chociaż osoby Jezusa, Maryi, jak i wiele innych postaci znanych z kart Pisma Świętego (Abraham, Mojżesz, Jonasz, Tobiasz, Izajasz...) są generalnie przedstawiani w sposób ortodoksyjny, to jednak we współczesnym teatrze, zwłaszcza młodzieżowym, ukazywani są oni jako bardzo ludzcy, bliscy człowiekowi, znający jego trudności. Formy zewnętrzne, często bardzo uwspółcześnione są przykładem, że dzisiejsi twórcy skupiają się nie tyle na wyjątkowości tychże postaci, ile wskazują na ich aktualność i atrakcyjność. Stąd wielka popularność i zainteresowanie współczesnych twórców teatralnych, aby różne osoby ze Starego czy Nowego Testamentu ciągle powoływać do scenicznego istnienia. 


\section{Summary \\ Biblical characters in modern \\ Polish religious theatre (after 2000)}

Christian theatre have repeatedly tried to convey the truths of faith by indicating different biblical characters to be role models. The characters of Jesus, Mary, and many more known from the Bible (Abe, Moses, Jonas, Tobiah, Isaiah) are generally depicted in an orthodox manner, however, in modern theatre, youth theatre in particular, they are depicted very human, close to man, aware of human difficulties. The external forms, often very modernized, prove that today's authors more than on unique nature of these character focus on their currentness and attractiveness. Hence, the modern theatre authors' great interest to bring to scenic life different characters from the Old and New Testament. 